\title{
Role of cholecystokinin receptor-A gene polymorphism in development of functional dyspepsia
}

\author{
Rajan Singh*, Balraj Mittal, Uday C Ghoshal \\ From International Conference on Human Genetics and 39th Annual Meeting of the Indian Society of \\ Human Genetics (ISHG) \\ Ahmadabad, India. 23-25 January 2013
}

\section{Background}

Functional dyspepsia (FD) is characterized by epigastric pain, burning, early satiety and post-prandial fullness in absence of organic or metabolic causes. Cholecystokinin receptor-A (CCK-AR) is known to modulate satiety signal and delay gastric emptying, which are associated with FD. $C C K-A R(\mathrm{rs} 1800857, \mathrm{~T} / \mathrm{C})$ polymorphism is associated with a defective splicing of the primary transcript of $C C K$ $A R$ mRNA, which may result in the lower expression of the $C C K-A R$. Therefore, we evaluated the role of genetic polymorphism of CCK-AR gene (rs1800857, T/C) in FD.

\section{Material and methods}

237 consecutive patients with FD (Rome III) and 250 healthy controls $(\mathrm{HC})$ were genotyped for $\boldsymbol{C C K}-\boldsymbol{A R}$ gene polymorphism (PCR-RFLP). Patients with FD were subclassified into epigastric pain syndrome (EPS), postprandial distress syndrome (PDS) and EPSPDS overlap.

\section{Results}

Patients with FD [173 (73\%) male, age 38 \pm 12 -y] were comparable with HC [195 (78\%) male, age $37 \pm 12$-y] with respect to age and gender. 26/237 (11\%) had EPS, 55 (23.2\%) PDS and 156 (65.8\%) EPSPDS overlap. Among 237 patients with $\mathrm{FD}, \mathrm{CC}$ (variant) genotype of $C C K-A R$ (rs1800857) was infrequent among patients than HC [19 (8\%) vs. $46(18.4 \%) \mathrm{p}=0.001$, odds ratio $(\mathrm{OR})=0.36,95 \%$ confidence interval $(\mathrm{CI})=0.19-0.66]$. However, genotypes distribution was comparable among patients with different subtypes of FD $(\mathrm{p}=0.44)$.

\footnotetext{
* Correspondence: rajan.lubiotech@gmail.com

Departments of Gastroenterology and Genetics, Sanjay Gandhi Postgraduate Institute of Medical Sciences (SGPGIMS), Lucknow-226014, India
}

\section{Conclusions}

CC genotype of $C C K-A R$ polymorphism is protective for FD. EPSPDS overlap was common among patients with FD.

Published: 21 January 2014

doi:10.1186/1755-8166-7-S1-P111

Cite this article as: Singh et al:: Role of cholecystokinin receptor-A gene polymorphism in development of functional dyspepsia. Molecular Cytogenetics 2014 7(Suppl 1):P111.

\section{Submit your next manuscript to BioMed Central and take full advantage of: \\ - Convenient online submission \\ - Thorough peer review \\ - No space constraints or color figure charges \\ - Immediate publication on acceptance \\ - Inclusion in PubMed, CAS, Scopus and Google Scholar \\ - Research which is freely available for redistribution \\ Submit your manuscript at www.biomedcentral.com/submit}

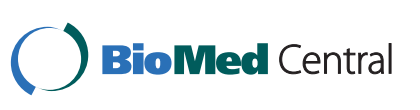

(c) 2014 Singh et al; licensee BioMed Central Ltd. This is an Open Access article distributed under the terms of the Creative Commons Attribution License (http://creativecommons.org/licenses/by/2.0), which permits unrestricted use, distribution, and reproduction in any medium, provided the original work is properly cited. The Creative Commons Public Domain Dedication waiver (http:// creativecommons.org/publicdomain/zero/1.0/) applies to the data made available in this article, unless otherwise stated. 